\title{
Kurgan ve Çadır Mimarisinden Güroymak Karanday Ağa (Kalender Baba) Kümbetine*
}

\section{From Kurgan And Tent Archıtecture to Güroymak Karanday Ă̆a (Kalender Baba) Cupola}

\author{
Özgür ÇETINTAŞa

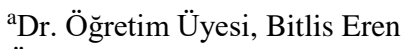 \\ Üniversitesi, Güzel Sanatlar \\ Fakültesi, Bitlis/Türkiye. \\ ozgurcetintas@gmail.com ORCID: \\ 0000-0001-6055-2892
}

\begin{abstract}
ÖZ
Türk sanatı ortaya çıktığı ilk çağlardan günümüze kadar bir bütün olarak ele alınacak olursa, tarihin her safhasında yaşanan gelişim aşamaları uzunca bir zincirin halkaları gibi takip edilebilir. Bu halkalar coğrafi, ekonomik ve kültürel etkenlerin değişimine göre zaman zaman farklılık gösterse bile yine de süreklilik arz eder. İslam öncesi devirlerden günümüze ulaşmayı başarabilmiş birçok balbal, tümülüs ve kurgan gibi yapılarla heykeller Türklerin bu dünyadan sonraki hayata olan inançlarını ortaya koymaktadır. Bu inanç İslam dininin Türkler tarafından kabul edilmesi ile birlikte farklı bir boyuta taşınmış olsa da kültür ve sanat alanında Türkler birbirinden önemli eserler vermeye devam etmiştir. Türk-İslam sanatları içerisinde dini mimariye ait eserler önemli bir yer tutmaktadır. Dini mimari grubu içinde sayabileceğimiz örneklerden olan kümbetler Anadolu'nun hemen her yerinde karşımıza çıkmaktadır. Özellikle Doğu Anadolu bölgesi çok sayıda kümbeti içinde barındırır. Anadolu'nun İslamlaşmasında önemli yeri olan Bitlis'in Ahlat ilçesi gerek Selçuklu Mezarlığı, gerekse kümbetleri bakımından ayrı bir zenginliğe ev sahipliği yapmaktadır. Anadolu Selçukluları dönemine ait onlarca kümbet ve farklı ölçeklerdeki mezarlıklar; bölgenin tarihi, sosyal ve kültürel açıdan önemini açıçca göstermektedir. Bu araştırmada Bitlis'in Güroymak ilçesinde bulunan ve halk arasındaki adıyla Kalender Baba Kümbeti olarak bilinen ancak, kitabesindeki adlandırmayla Karanday Ağa Kümbeti mimari özelliklerinin yanı sıra yazı ve süsleme elemanları bakımından incelenecektir.
\end{abstract}

Anahtar Kelimeler: Türk, Orta Asya, Kurgan, Kümbet, Süsleme, Yazı, Dini Mimari.

\begin{abstract}
If Turkish art is considered as a whole from the first ages of its emergence to the present, the stages of development experienced at every stage of history can be followed like the links of a long chain. Even if these rings differ from time to time according to the change of geographical, economic and cultural factors, they still remain continuous. Many structures such as balbals, burial mounds and kurgans and sculptures that have survived to the present day from pre-Islamic era reveal the belief of Turks in life after this world. Although this belief moved to a different dimension with the acceptance of Islam by the Turks, Turks continued to produce important works in the field of culture and art. Works of religious architecture have an important place in Turkish-Islamic arts. Domes, one of the examples that we can count in the religious architecture group, can be found almost everywhere in Anatolia. Especially the Eastern Anatolia region hosts many cupolas. Ahlat district of Bitlis, which has an important place in the Islamization of Anatolia, hosts a separate richness in terms of both the Seljuk Cemetery and its cupolas. Dozens of cupolas and cemeteries of different scales belonging to the Anatolian Seljuk period; clearly shows the historical, social and cultural importance of the region. In this study, the Karanday A ğa Vault, which is located in Güroymak district of Bitlis and known as Kalender Baba Cupola by the public, but named in its inscription, will be examined in terms of writing and decorative elements as well as architectural features.
\end{abstract}

Keywords: Turk, Middle East, Kurgan, Cupola, Ornamentation, Inscription, Religious Architecture.

\footnotetext{
* Bu makalede bilimsel araştırma ve yayın etiği ilkelerine uyulmuştur. / In this article, the principles of scientific research and publication ethics were followed.
} 


\section{GíRiș}

İnsanoğlunun temel ihtiyaçlarından biri barınmadır. Bu ihtiyacın karşılanması 1rk, din, sosyal veya ekonomik statü gibi kaidelere bağlı olmaksızın zaruriyet arz etmektedir. İnsanın hayatını güven içerisinde sürdürebilmesi için barınaklar inşa etmesi gibi; sevdiklerini ölümden sonraki hayata hazırlamak ve cenazelerini yırtıcılardan, yağmacılardan koruyabilmek maksadıyla da mezar mimarisinin geliştirildiğini düşünebiliriz.

Proto-Türk topluluklarında "yurt” adı verilen çadırlar kullanılmaktadır. Büyük Hun Devleti kurulmadan hemen önce, proto-Hun kültürü olarak niteleyebileceğimiz Tagar Kültürü devresinde Orta Yenisey’de yani Kem Havzası'nda, Boyar mıntıkası petrogliflerinde MÖ. VII-VI. yüzyıllara tarihlenen bozkır yaşamını betimleyen sahnelerde gövdesi yuvarlak, çatısı kubbe şeklinde çadır tasvirlerine rastlanmaktadır (Çoruhlu, 2017: 120). Kurgan ise kelime anlamı olarak "kütüklerden ahşap yığma tekniğiyle yapılmış bir mezar odasını gizleyen bir toprak yığınından oluşur, İslamlık öncesi dönemde özellikle Orta Asya’nın kuzey kesiminde yapılmıştır (Sözen \&Tanyeli, 2014: 183)” şeklinde tanımlanmaktadır.

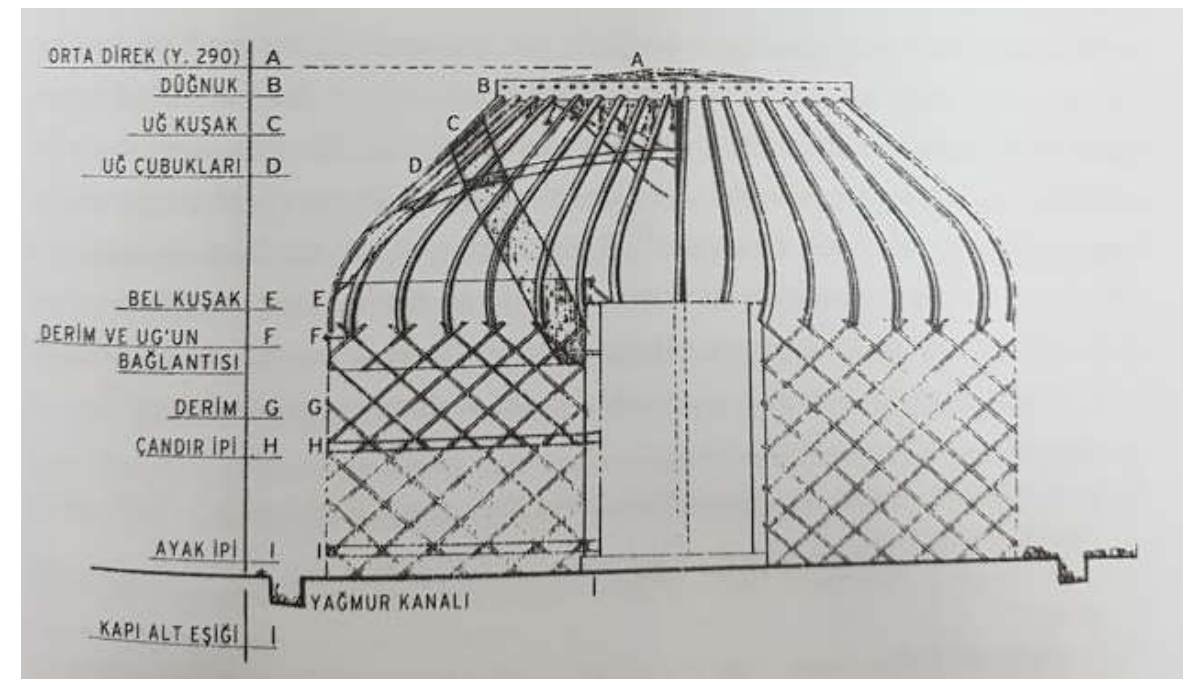

Şekil 1: Türkmen çadırının bölümlerini gösteren şema (Çoruhlu, 2017: 123).

Eski Türk topluluklarında kurganların (mezar), insanların gündelik yaşam alanlarına oldukça yakın yapıldığı arkeolojik kanıtlarla sabittir. Buradan hareketle Türklerde tarihin başından beri ölüm ve yaşam kavramlarının bir arada düşünüldüğü söylenebilir. Tanımlarını verdiğimiz kurgan ve yurt adı verilen çadırların bir arada yorumlanmasıyla, Anadolu Selçuklu kümbetlerinin benzerlikleri dikkat çekicidir. Anıtsal mezar fikri İslam inancıyla pek bağdaşmasa gerektir. Bu sebeple, İslam kültürünün temelinin atıldığı bölgelerde X. yüzyıla kadar çok ender türbeye rastlanmaktadır (Arık, 1967: 57).

Selçuklular XI. yüzyılda Suriye'den Semerkand'a kadar yayılan çok güçlü bir devlet kurmuşlardır. Zamanla bu büyük devlet İran Selçukluları, Suriye Selçukluları ve Anadolu Selçukluları olmak üzere üçe bölünmüştür. İran'da Sasani üslubu devam ederken Suriye ve Anadolu'da yepyeni bir sanat anlayışı doğmuştur (Arseven, 1984: 54). Bu sanat zevkinin ortaya çıkmasında farklı toplumsal yaşamlar, inançlar, gelenekler, sanatlar, devletler, beylikler gibi çeşitli faktörlerin etkileri düşünülebilir. Anadolu Selçukluları bunları yeniden ele alarak kendilerine özgü bir sanat tarzı oluşturmuşlardır. Çağlar boyunca Anadolu'da süre gelen özellikle Hitit, Urartu, Roma ve Bizans dönemlerinin Selçuklu sanatı üzerine etkilerinin olduğu da kuşkusuzdur (Şahin, 2014: 8). Bu sanat tarzı; Türklerin Orta Asya'dan getirip İran üzerinden Anadolu'ya taşıdığı sanat ve estetik kaidelerini, Anadolu'da karşılaştığı Bizans etkisiyle harmanlayarak Anadolu'da Türk-İslam üslubu haline evrilmiştir. Yüzyıllar sonra bu üslup Osmanlı ve onun devamında gelen Cumhuriyet dönemi sanat anlayışında kendini devam ettirmektedir.

\section{ANADOLU SELÇUKLULARINDA KÜMBET MIMARİSİ VE YAZI - SÜSLEME ANLAYIŞI}

Medeniyet tarihi açısından zengin bir geçmişe sahip olan Anadolu Yarımadasında hüküm sürmüş her topluluk ve medeniyet kendi kültürlerinin miraslarını bırakmışlardır. Bir önceki toplumsal yaşamı simgeleyen her karakter diğer uygarlıklara aktarılmıştır. Varoluş süreleri ya da hükümranlık alanlarına paralel olarak kültürel etki oranı artsa da küçük toplulukların da etkilerinin yansımalarına rastlanılmaktadır. Karma bir ifade kültürünün doğmasına yol açan tarihsel aktarım ortak bir coğrafik etki silsilesini tetiklemiştir. Bu etkileşim, yaşamın her alanında var olmasının yanı sıra bariz görüldüğü alanlardan birisi de mimaridir. Anadolu Selçukluları, Anadolu medeniyetlerinin getirdiği ortak mirastan esinlenerek kendi mimari yapılarında geçmiş uygarlıkların izlerini taşıyan örnekler sergilemişlerdir. Anadolu Selçuklu mimari yapılarının temel yapım aşamalarından, detaylı süslemelere kadar farklı açılardan etkiler günümüzde dahi gözlemlenmektedir. Anadolu Selçuklu mimarisinin en yaygın örneklerinden biri olan kümbetlerde bahsedilen ortak miras etkileri bulunmaktadır.

Sözlük anlamı olarak kümbet, "Üstü koni veya piramit şeklinde bir külahla örtülmüş olan türbelere, özellikle de Selçuklu devri türbelerine verilen isim (Çam, 2016: 243)" olarak tanımlanmaktadır. Kümbetler yalın bir gözle incelendiğinde yer 
seviyesinin altında kalan cenazelik (kripta) ve onun üstüne inşa edilen ibadet / ziyaret alanıyla yaşam ve ölümün aynı yapıda bir araya getirilmesi olarak nitelendirilebilir.

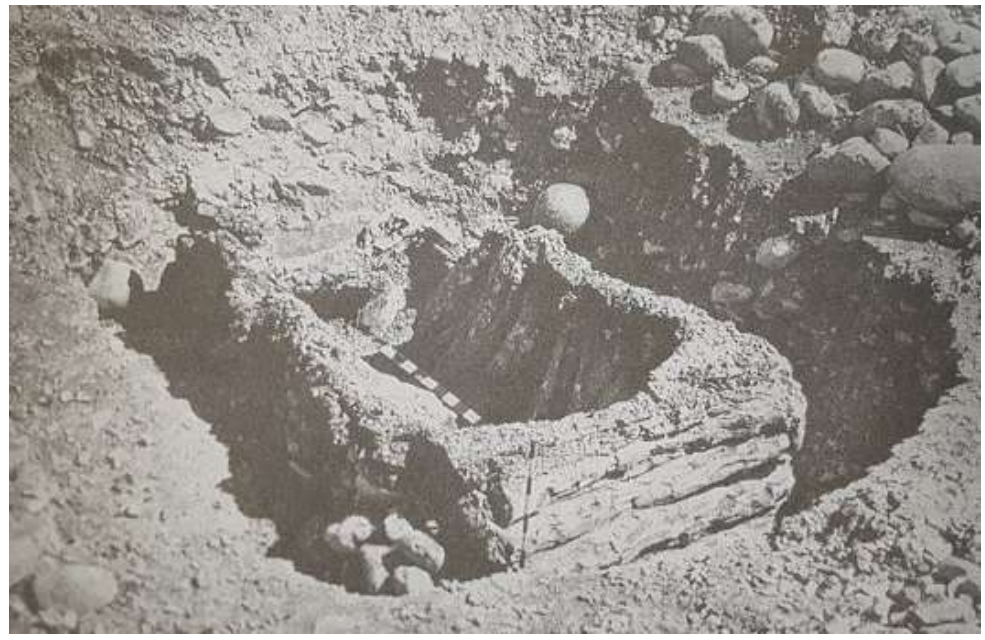

(a)

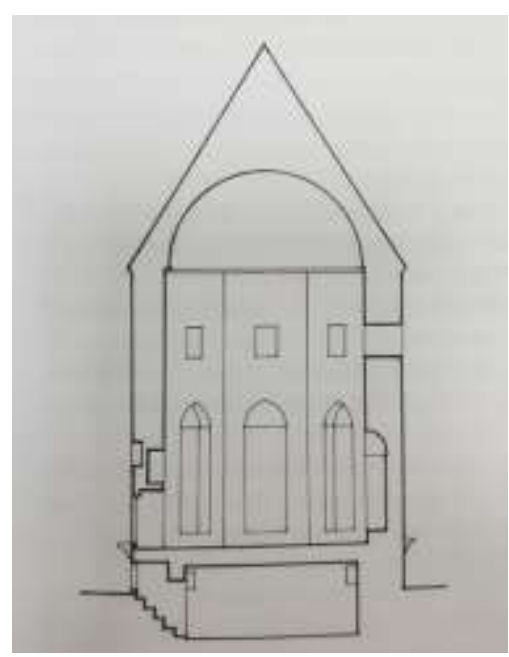

(b)

Şekil 2: Isık Kurganı (a) (Çoruhlu, 2017: 108) ve Kayseri Lala Muslihuddin Türbesi (b) kesiti (Önkal, 2015: 61).

Selçuklularda kubbeli türbe yoktur, sadece kümbetler yapılmıştır. Bunlarda kubbe çatının altında gizlidir. Dışarıdan konik veya piramit çatı görünür (Söylemez, 2016: 37). Selçuklu mimarisinin yarattığı en orijinal eserlerden biri kümbetlerdir. Anadolu Selçuklu kümbetleri, Nahçivan, Rağdan ve Gürgan'daki ilk öncüleri kadar başarılı olmakla beraber, daha dengelidirler; ölçülerindeki uygunlukla bunlardan geri kalmazlar. Hatta mimari ahenkleri yönünden daha da göz doyurucu sayılabilirler (Eldem, 1976: 5). Anadolu'da büyük bir inşa faaliyeti gösteren Selçukluların bu yapılarda kullandığı ana malzeme taştır. Anadolu Selçukluları, ağırlıklı olarak tuğla malzemenin kullanıldığı İran Selçuk mimarisinden sonra, Anadolu'ya büyük yenilikler getirmiştir (Öney, 1992: 9). Taş ve tuğlanın süsleme ve yapı malzemesi olarak İran'dan sonra en geniş ve çeşitli kullanım alanı Anadolu Selçuklu mimarisinde görülmektedir. Sadece taş ve tuğla değil; bunların yanı sıra ahşap, çini, çini mozaik gibi malzemeler de yapılarda inşa ve süsleme unsuru olarak geniş yer bulmuştur. Anadolu'nun hemen her yerinde görülen Selçuklulara ait dini, sivil ve askeri mimari eserlerinde bu malzemelere rastlamak mümkündür. Anadolu Selçuklu döneminde inşa edilmiş kümbetlerin süsleme programında geometrik motifler öne çıkmaktadır. Sıklıkla kullanılan motifler arasında yıldızlar, çokgen geçmeler, zincir motifleri, altıgenler ve bu motiflerin arasında kalan boşluklara uygulanan diğer geometrik ve bitkisel desenler sayılabilir. Geometrik desenlerin yanı sıra bitkisel süsleme ve yazı panoları da mimari yapılarda süslemeye ait önemli unsurlardandır. Anadolu Selçuklu dönemi bitkisel süslemelerinde kullanılan motifler ağırlıklı olarak kıvrık dallar, üsluplaştırılmış / stilize edilmiş çiçek motifleri ve bazı araştırmacılara göre hayvansal motif grubu içinde sayılan rumi desenleri olarak sıralanabilir. Mimari yapılarda görülen yazı çoğunlukla kitabe diye adlandırılan panolarda yer almaktadır. 11 ve 13 . Yüzyıllar arasında sadece mimaride değil, günlük yaşamda da kullanılan ve Türk hat ekolünün önemli bir safhasını teşkil eden Selçuklu sülüsü bu dönem kitabelerinde sıkça karşımıza çıkmaktadır. Genellikle yatay silmeler kullanılarak birbirinden ayrılan kitabe satırları yazının yanı sıra, yer yer bitkisel süsleme motifleri de içermektedir. Bazı kitabelerde, kuşak yazılarında veya mihrap yazılarında yine bu dönemin karakter özelliği olarak dik harflerin zülfe adı verilen kısımlarının rumi motifiyle birleştirildiği görülmektedir. Özellikle Anadolu Selçuklu hükümdarlarının inşa ettirdiği selatin camileri gibi büyük ölçekli yapılarda yazının bu tip süsleme unsurlarıyla ve kıvrık dallar gibi daha girift kompozisyonlarla iç içe tasarlandığı örneklere sıkça rastlanmaktadır. Camilerde vaz geçilmez bir unsur olan kuşak yazıları, kümbetlerde dış cephede bazen sadece yazı kuşağı bazen de süslemeyle birlikte görülmektedir.

\section{BITLIS TARIHINE GENEL BAKIŞ}

1110-1207 yılları arasında Van Gölü havzasında hüküm süren Sökmenliler (Ahlatşahlar), Erzincan Bölgesinde Mengücükler (1080-1228), Güneydoğu Anadolu'da Artuklular (1102-1409) ve Anadolu’da konuşlanmış diğer birçok Türk Beyliği Anadolu'nun bir Türk yurdu haline gelmesinde önemli rol oynamışlardır. Malazgirt Zaferi ve bu zaferin kahramanı Sultan Alparslan'ın tarihimize en büyük armağanı, bugün üzerinde yaşadığımız toprakların baştan sona fethederek bağımsız bir devlet haline getirmiş olmasıdır (Sevim, 1988: 75). 11. Yüzyıldan 13. Yüzyıla kadar bir şekilde Selçukluların elinde kalan Ahlat bölgesi, 13. Yüzyılda Karakoyunlu Devleti, sonrasında Akkoyunlu Devleti, 1473'de Akkoyunluların yıkılmasıyla Safevi hakimiyetine geçmişse de 1517 yılında Yavuz Sultan Selim'in Çaldıran Savaşı ile Osmanlı Devleti topraklarına katılmıştır (Erken, 1977: 122).

Doğu Anadolu bölgesi, Anadolu Selçuklularının başkentleri olan Konya'dan sonra imar faaliyetlerinin belki de en yoğun görüldüğü coğrafi bölgemizdir. Mimarinin her alanında (askeri, sivil ve dini mimari) birbirinden güzel yapılara bu bölgede rastlamak mümkündür. Özellikle başkent Konya'daki Alaaddin Camii, Anadolu Selçuklu mimarisinde selatin camilerinin güzel bir örneğidir. Benzer şekilde Gök Medrese, Sivas’ta Anadolu Selçuklularının taş süslemeciliğindeki seviyesini ortaya koyması bakımından eşsiz bir eserdir. Bitlis ili ve ilçeleri de Anadolu Selçuklularına ait kümbet, medrese ve mezarlık gibi dini yapı grubuna ait eserlerin bulunduğu bir bölgemizdir. Karanday Ağa kümbeti Bitlis il sınırları içinde bulunan onlarca kümbetten 
biridir. Anadolu Selçuklularına ait kümbetlerin büyük çoğunluğu Bitlis’in yaklaşık 20 km kuzey doğusunda yer alan Ahlat ilçesinde inşa edilmiştir. Ev sahipliği yaptığı kümbetlerden çok Selçuklu açık hava mezarlığı ile tanınan Ahlat ilçesi, Anadolu Selçuklularından günümüze intikal eden değerli bir kültür envanterine sahiptir. Selçuklu Mezarlığı, içinde barındırdığı Kadılar Mezarlığı ile Ahlat bölgesinin Anadolu Selçukluları açısından idari önemini ortaya koymaktadır.

Bitlis ilindeki Anadolu Selçuklularına ait yapılar yalnızca Ahlat ilçesi ile sınırlı değildir. Bu araştırmamızda ele aldığımız Karanday Ağa kümbeti şehir merkezine yaklaşık 30 km mesafede bulunan Güroymak ilçesinde inşa edilmiştir. Karanday Ağa kümbeti ile aynı bahçe içerisinde yer alan küçük mezarlıkta, tıpkı Ahlat ilçesindeki Selçuklu Mezarlığında görülen örneklere benzer mezar taşları bulunur. Buradaki mezar taşları da Ahlat'takiler gibi düzgün kesilmiş ve oymalarla işlenmiş kırmızı Ahlat taşından yapılmıştır. Ahlat Selçuklu Mezarlığında bulunan sandukalı mezarlara burada rastlanmamaktadır. Bahçenin durumundan henüz mezarların tamamının gün yüzüne çıkarılmamış olabileceği düşünülse de halihazırdaki mezar taşları Ahlat örneğinin minyatürü olarak karşımıza çıkmaktadır. Büyük ölçekli Ahlat Mezarlığındakiler gibi, Karanday Ağa kümbeti bahçesinde yer alan taşlarda da yer yer kandil motifleri, bu motifler içine yazılmış Allah ismi ve bazı taşların üst kısmında mukarnas işlemeleri görülmektedir. Ahlat Selçuklu Mezarlığında yer alan mezar taşlarının bir çoğunda özellikle üst kısımlarda Türk mitolojisinin önemli sembollerinden olan ejder motifleri işlenmiştir. Yine Ahlat'taki sandukalı mezarların yan yüzlerinde bitkisel veya rumi motiflerle iç içe işlenmiş Selçuklu sülüsü karakterinde yazılar mevcuttur. Karanday Ağa kümbeti bahçesindeki mezar taşlarında sayılan bu süsleme örnekleri görülmemektedir. Bu mezarlıktaki taşlar Ahlat mezarlığındakilere göre çok daha yıpranmış durumdadır.

Kümbetle ilgili daha eski kaynaklarda yer alan fotoğraflarda yapının neredeyse tamamen yıkıldığı görülmekte ve yeniden onarımına başlandığı belirtilmektedir (Erken, 1977: 230). Karanday Ağa kümbeti ile ilgili bir başka araştırma da Prof. Dr. Hakkı ÖNKAL'ın Anadolu Selçuklu Türbeleri adlı eserinde karşımıza çıkmaktadır. Bu eserde yapının ölçüleri, plan tipi, inşa tekniği gibi bilgilerin yanı sıra eserin kitabesi ve tarihlendirme gibi bilgiler de yer almaktadır. Kitabenin en doğru çevirisi bu eserde görülmektedir. Kümbet ile ilgili literatür taraması yaparken ulaşabildiğimiz en eski kaynak Orhan Cezmi TUNÇER'e aittir. 1976 yılında yayınlanan "13. Yüzyıla Ait Üç Kümbet” adlı araştırmasında Diyarbakır Sultan Şücaeddin Türbesi ve Tunceli-Mazgirt Elti Hatun Türbesi ile birlikte Güroymak’taki Karanday Ağa Kümbeti'ne "Bitlis- Güroymak (Norşen) Kümbeti” adıyla yer vermiştir. Anacak eserin kitabesinin ikinci satırı Türkçeye çevrilirken isim kısmı okunamamış "intikal” bölümü de "inte kalemin" olarak tercüme edilmiştir. Bu eserlerde Karanday Ağa kümbeti ile ilgili ortak nokta, kümbetin yıkıldıktan sonra Ahlat kümbetleri örnek alınarak yeniden inşa edildiği bilgisidir. Bahsettiğimiz ilk eserde Karanday Ağa kümbetinin kitabesine ilişkin bir açıklama yer almamaktadır. Yapının süsleme özelliklerine değinilmiş ve o dönem için sağlam kalan kısımlarının ölçüleri ve plan tipi açıklanmıştır.

\section{KARANDAY AĞA KÜMBETİ (M. 1290)}

$\mathrm{Bu}$ araştırmanın konusu olan Karanday Ağa (Kalender Baba) kümbeti, Bitlis il merkezinden Muş’a giderken yaklaşık 30. kilometrede bulunur. Yapı, bahçe duvarı içerisinde yer almaktadır. Aynı bahçe içerisinde (Ahlat mezarlığına benzerliği sebebiyle) 13. Yüzyıldan kalma olduğu anlaş1lan mezarlarla birlikte günümüze ait mezarlar da görülmektedir. Kümbet, mimari ve süsleme özellikleri bakımından Ahlat ilçesindeki Anadolu Selçuklu dönemi kümbetleriyle benzerlik göstermektedir. Aynı şekilde Karanday Ağa Kümbeti bahçesindeki mezarlar da Ahlat Selçuklu Mezarlığındakilerle çok benzer formlara ve süsleme unsurlarına sahiptir. Yapı, bölgedeki diğer kümbetlerle benzer özelliklere sahiptir. Bu durum bahsi geçen tarihi eserlerin yakın dönemlerde Kültür Bakanlığı ve Vakıflar Genel Müdürlüğü gibi kurumlarca onarılmasından ileri gelmektedir. Konuyla ilgili geçmiş dönemlerde yazılmış kaynaklar sadece Karanday A ğa Kümbeti’nin değil, bölgedeki birçok kümbetin yıkılmış bir halde bulunduğunu bize aktarmaktadır.

Yapı, Ahlat’taki Buğatay Aka ve Hüseyin Timur Türbelerinin kopyası niteliğindedir. Bu yapılardaki benzerlik süsleme bakımından Ermeni dini yapılarında da görülmektedir (Tunçer, 1978: 244). Yapı malzemesi, plan ve süsleme özellikleri bakımından büyük benzerlikler gösteren Karanday Ağa ve Hüseyin Timur kümbetleri aynı döneme ait eserlerdir. Her ikisi de Anadolu Selçuklu dönemi kümbetlerinin tipik özelliklerine sahiptir. Yer seviyesinin altında yer alan cenazelik / mezar odası (kripta) ve onun üstüne inşa edilen ibadet / ziyaret bölümü neredeyse ölçülerine kadar aynıdır. Her iki yapı da dış cephelerinde uygulanan taş süslemelerde bile neredeyse aynı ustanın elinden çıkmışçasına birbirine benzemektedir. Bu benzerliklerin yanı sıra Hüseyin Timur kümbetinin sahip olduğu dört adet kitabe yapılar arasındaki başlıca farklardan biri olarak sayılabilir. Ayrıca Karanday A ğa kümbetinin çatı kuşağının hemen altında mukarnas sırası yer alırken Hüseyin Timur kümbetinde bahsi geçen bölümde beyaz kireç taşına kabartma olarak uygulanmış yazı ve süsleme kuşağı bulunur. Anadolu Selçuklu türbelerinin klasik plan tipi burada da uygulanmıştır. Köşeleri pahlanarak kırılan kare kaide üzerinde yükselen silindirik gövdenin sivri külah (konik) tipi örtü kullanılarak kapatılmasıyla oluşan yapı, beden duvarlarındaki silmelerin çevrelediği panolar ve kapı lentosu üzerinde konumlanan kitabe ile döneminin mimari anlayışını yansıtması bakımından güzel bir örnektir. 


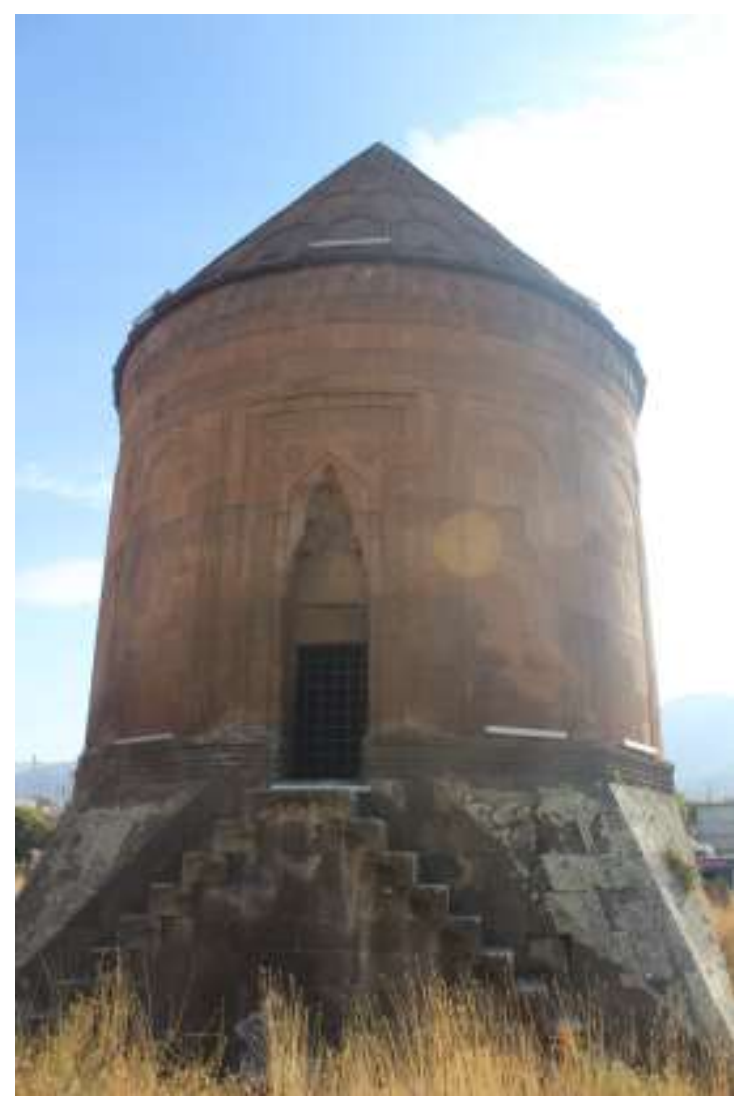

(a)

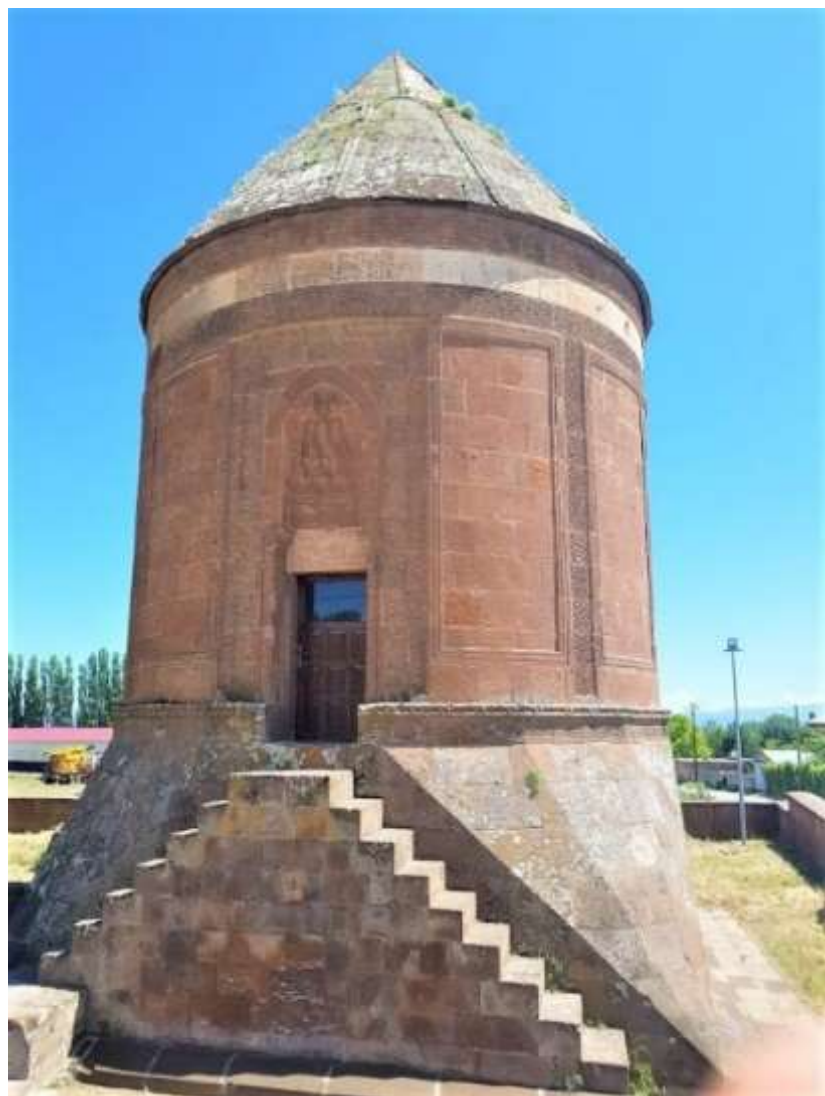

(b)

Şekil 3: Karanday Ağa (a) ve Hüseyin Timur Kümbeti (b) kuzey cephesi (Çetintaş, 2020-2018).

Silindirik gövde her kenarı yaklaşık 8 metre uzunlukta ve köşeleri pahlanarak on iki kenarlı bir poligona dönüştürülen kare kaideye oturmaktadır. Kaide ve içerisinde yer alan mezar odası / cenazelik (kripta) için kullanılan malzeme siyah renkli kesme taştır. Bu kaidenin 1,20 metrelik bölümü yerin altında bulunmaktadır. Günümüzde kilitli olan cenazelik (kripta) kısmına zeminden merdivenle inilmektedir. Cenazeliğin iç ölçüleri 6,18 x 6,18 m. ölçülerdedir (Tunçer, 1976: 95). Bu bölümü havalandırmak amacıyla biri kapı üzerinde (doğu cephe), diğeri bunun tam karşısında ve sonuncusu güney yönünde olmak üzere üç penceresi bulunmaktadır. Pencerelerin hemen üstünde birer adet kabartma rozet motifi görülmektedir.

Üst kat girişi diğer Ahlat türbelerinde olduğu gibi kuzey cephede yer almaktadır (Önkal, 2015: 196). Kapının köşeliklerinde sütunceler ve beş sıralı mukarnasla sonlanan bir niş bulunmaktadır. Kapı nişi iki silme ile çevrelenmiştir. Kapı lentosunda merkezdeki beş köşeli yıldızlardan uzayan çizgilerin oluşturduğu çokgen geçmelerden meydana gelmiş geometrik panodan sonra kitabe görülmektedir. Yazı panosunun üstünde taşa oyma olarak işlenmiş yaklaşık $30 \mathrm{~cm}$ çapında dairevi bir rozet motifi yer almaktadır. Yapının silindirik gövdesinde kullanılan kırmızı Ahlat taşının aksine, kitabe beyaz renkli kireç taşına kabartma olarak yazılmıştır.

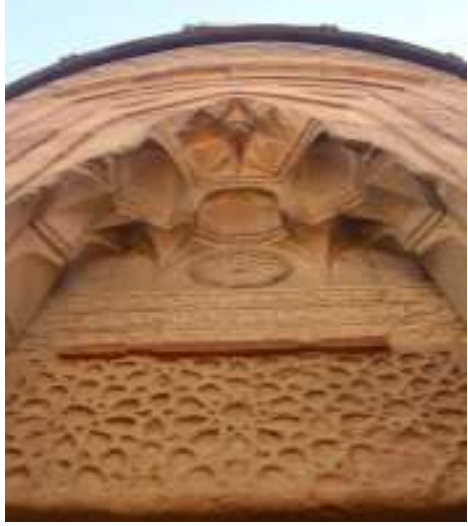

(a)

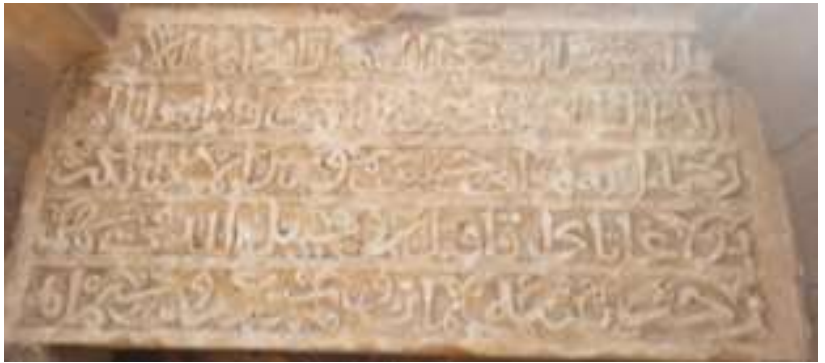

(b)

Şekil 4: Karanday Ağa Kümbeti (a) kapı üstü yazı ve süsleme elemanları ve Hüseyin Timur Kümbeti (b) birinci tarih kitabesi. (Çetintaş, 2020-2018.). 
Yapının silindirik gövdesini oluşturan beden duvarları muntazam kesme Ahlat taşı ile örülüdür. Yapının gövdesinde güney, doğu ve batı yönlerinde üç adet pencere bulunur. Bu pencereler niş içerisinde yer alır ve dörder sıra mukarnas ile sonlanmaktadır. Yapı külah tipi konik örtü ile kapatılmış ve külahın yüzeyi silmelerle panolara bölünmüştür. Bu panolarda basit süsleme elemanları görülmektedir. Yapının bütününde kullanılan inşa malzemesi bölgedeki tüm tarihi yapılarda olduğu gibi Ahlat taşıdır.

Anadolu Selçuklu türbelerinde süsleme daha çok dış yüzeylerde yoğunlaştırılmıştır. Kapı nişi, çevresi ve pencerelerde geometrik, bitkisel bezemeli bordürler, kaval silmeler, mukarnaslar yer alır. Yanlarda oluşturulan boşluklarda rozetler, gülbezekler yerleştirilmiştir. Bu süsleme programı Türk çadırlarını hatırlatmaktadır (Karpuz, 2004: 68). 13. yüzyıl, taş süslemeleri bakımından en ileri adımların atılarak adeta geometrik bezemelerde altın çağın yaşandığı bir dönemdir (Mülayim, 1982: 28). Nitekim Karanday Ağa Kümbeti, süsleme bakımından Ahlat’taki Buğatay Aka ve Hüseyin Timur Türbeleriyle büyük benzerliklere sahiptir. Yapının gövdesi Buğatay Aka Türbesinde olduğu gibi ince silmeler kullanılarak on iki dikey panoya bölünmüştür. Kare plandan dönüştürülen kaide yatay bir geçme motifiyle sonlanmaktadır. Bu geçme motifleri, hasır örgüsü gibi bir alttan bir üstten birbirini kat eden şeritler olarak tanımlanmaktadır. En eski tezyini motiflerdendir (Ögel, 1987: 83). Bu süslemenin üzerinde yer alan pencerelerin etrafındaki dikdörtgen kuşaklar çokgenlerin oluşturduğu bordürlerle süslenmiştir. Pencere alınlıklarında, kitabenin altında yer alan geçme panosu tekrarlanmıştır. Üst kısımdaki mukarnasları çevreleyen nişin iki yanına kabartma rozet motifleri yerleştirilmiştir. Aralarda yer alan dikey panolar silmelerle çerçevelenmiştir. Bu silmeler basit geçmeler şeklinde olup tezyinatsızdır. Pencerelerin üst hizasında yatay kuşak süslemesi yapıyı dolaşmaktadır. Bu kuşak süslemesi, dikey düzlemde pencerelerin arasındaki silmelerden oluşan boşluğu doldurmaktadır.

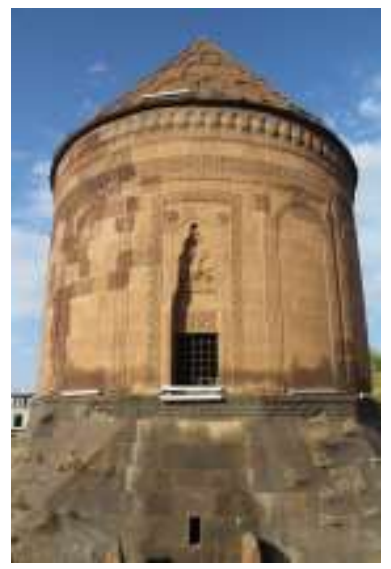

(a)

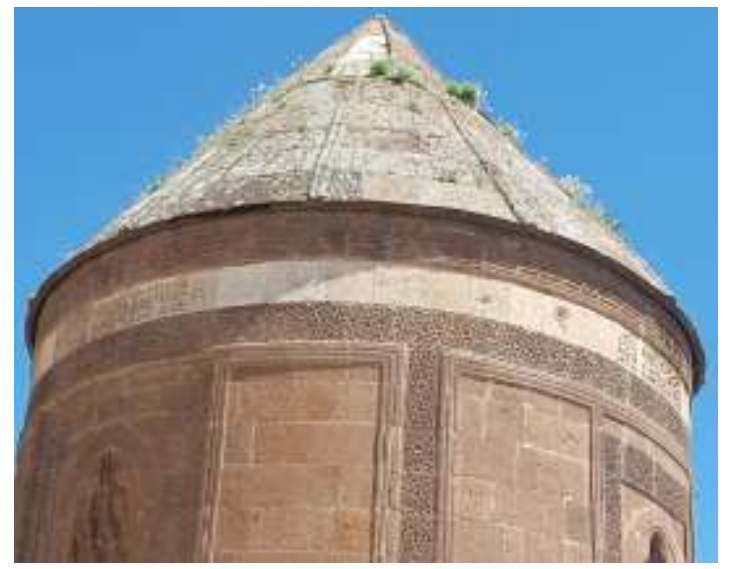

(b)

Şekil 5: Karanday Ağa Kümbeti (a) güney cephe ve Hüseyin Timur Kümbeti (b) beden duvarı panoları (Çetintaş, 2020-2018).

Yapının güney cephesinde bulunan pencere, kuzey cephede konumlanan kapı ile benzer süsleme özelliklerine sahiptir. Kapı üzerinde görülen geometrik panonun aynısı devamındaki dört sıra mukarnaslarla birlikte burada da tekrarlanmıştır. Kapı üstündeki kitabe için ayrılan pano, pencere üzerinde de bulunur ancak burada boş bırakılmıştır. Mukarnasların üst kısmındaki sivri kemerin sağ ve sol üstünde kabartma rozet motifleri bulunur. Panoda yer alan geometrik motiflerin aynısı pencerenin alt kısmında kaideden başlayarak pencerenin üç tarafını bordür oluşturacak şekilde dolaşır. Pencere bölümü için ayrılan alanı sağ ve solundaki diğer panolardan ayırmak maksadıyla dikey silmeler kullanılmıştır. Bu dikey silmeler belli aralıklarla düğ̈̈mlenmek sureti ile basit bir zencerek motifi meydana getirilmiştir.

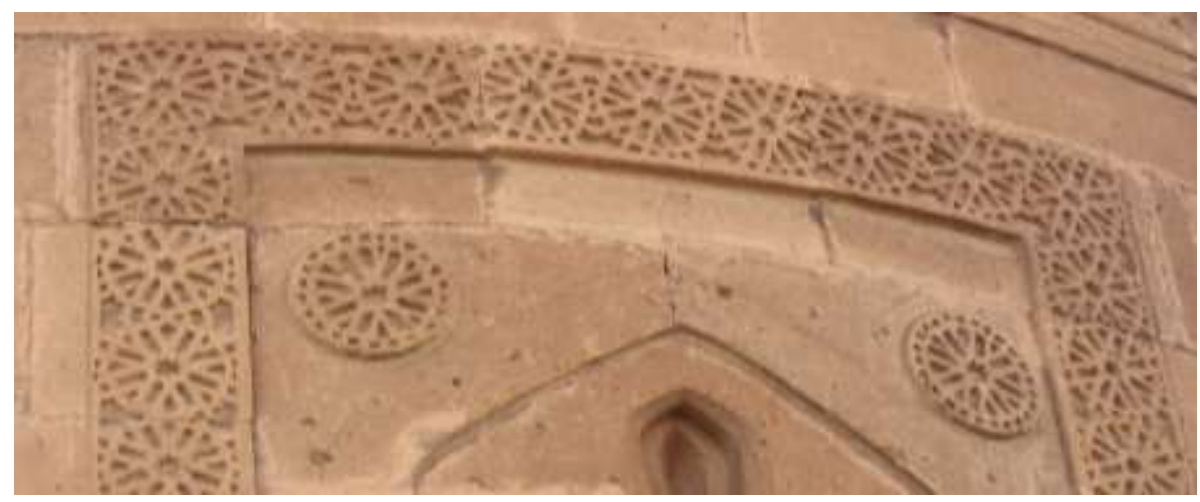

Şekil 6: Karanday Ağa Kümbeti pencere süslemesi detayı (Çetintaş, 2020).

Pencereyi çevreleyen bordürün üst kısmı incelendiğinde geometrik geçmelerin kesintiye uğradığı, nizami şekilde birbirine bağlanmadığı görülmektedir. Yapılan onarım işleminin izleri burada anlatıldığı gibi kümbetin farklı noktalarında da kendini belli etmektedir. Yapının tamamına yakınının yıkıldığı düşünüldüğünde bu durum normal karşılanabilir. 
Kümbetin kitabesi beyaz renkli kireç taşına kabartma olarak yazılmıştır. Üç satırlık kitabenin ikinci satırının baş ve son kısmına basit bir motif uygulanmıştır. Böylece ilk ve son satırı, orta satıra göre daha kısa bir görünüm sunmaktadır. Dendanlı yatay dikdörtgen bir çerçeve içine alınan kitabenin son satırında yer yer yıpranmalar görülür. Bu yıpranma isim kısmına değil, sonrasına denk gelmektedir. Kümbetle ilgili yayınların bir kısmında kitabenin çevirisi yapılırken bu bölüm boş bırakılmıştır. Türkiye'de Vakıf Abideler ve Eski Eserler isimli Vakıflar Genel Müdürlüğü’nün 1977 yılında yayınladığı eserin 228. Sayfasında kümbet tanıtılırken kitabenin çevirisi yapılmamıştır. Orhan Cezmi Tunçer'in “13. Yüzyıla Ait Üç Kümbet” adlı makalesinde de isim kısmı çevrilmemiştir. Aynı eserde kümbet tanıtılırken bölgedeki yaşlılar tarafından kümbetin "Kalender Baba Kümbeti" adıyla anıldığı ancak neden bu ismin verildiğinin öğrenilemediği belirtilmiştir. Tahminimize göre kitabede geçen "Karanday Ağa" ismi halk arasında "Kalender Baba" olarak zamanla değiştirilmiş olabilir. Kümbetin etrafında, diğer Ahlat kümbetlerinde olduğu gibi tanıtım levhaları bulunmamaktadır.

Kümbetin kitabesinde yer yer harekeler, hatta tezyini motifler görülebilmektedir. Satır araları yatay silmelerle birbirinden ayrılan kitabenin bir diğer dikkat çekici özelliği, yazı alanı dışında kalan dört köşede “Allah, Rahman, Rahim” gibi besmeleye ait yazı parçalarının çok temiz şekilde görülebilmesidir. Kitabe alanının dışında kalan bu yazıların ne amaçla oraya hakkedildiği anlaşılamamıştır.

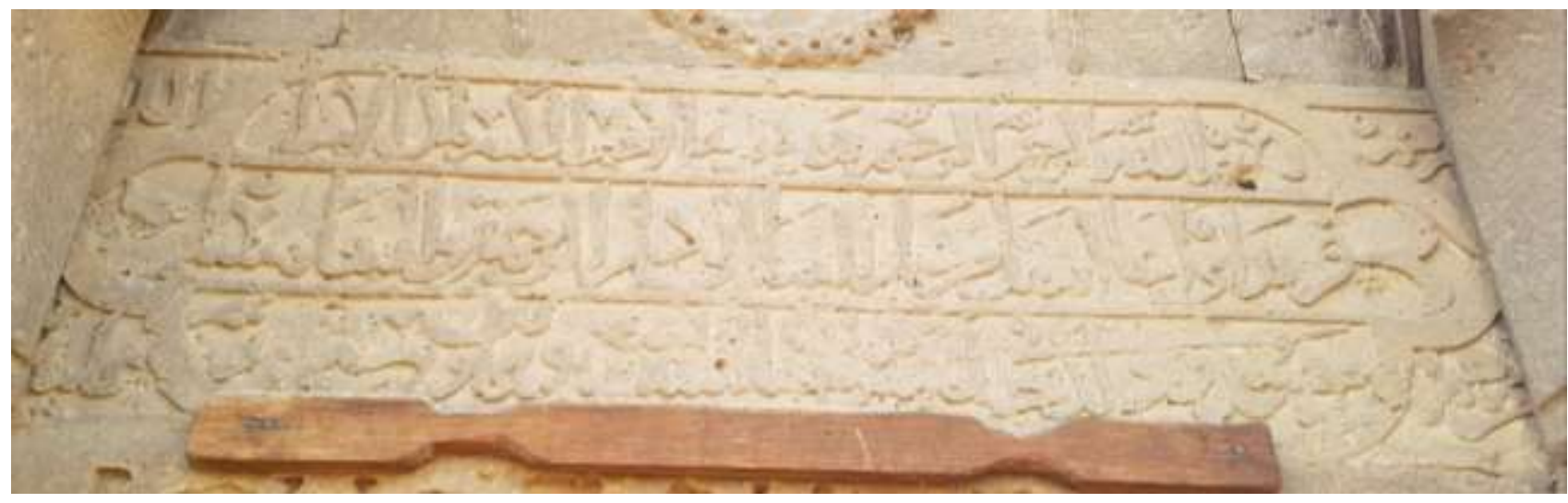

Şekil 7: Karanday Ağa Kümbeti kitabesi (Çetintaş, 2020).

Kitabede kullanılan yazı Selçuklu sülüsüdür. Selçuklu sülüsü adlı yazı karakteriyle ilgili detaylı bilgi için 2019 yılında yayınlanmış olan “Ankara Alaeddin Camii Kitabelerinin Hat Sanatı Yönünden İncelenmesi” başlıklı makaleye bakılabilir. Ancak burada kısaca belirtmek gerekirse elif, lam gibi dik harflerin tepede kalın başlayıp giderek incelmesi; mim ve vav gibi gözlü harflerin yuvarlak şekillerde yapılmaları ve harf bağlantılarındaki görece keskin dönüşler bu yazının karakteristik özelliklerinden bazıları olarak sıralanabilir. 11. yüzyıldan itibaren gelişmeye başlayan ve Osmanlı'nın erken dönemlerine kadar kullanılan Selçuklu sülüsü en güzel formuna 13. yüzyılda ulaşmıştır. Karanday Ağa Kümbeti de kitabesinden anlaşıldığına göre 1290 senesinde inşa edilmiştir.

Kitabenin Arap harfleriyle yazılışı ve günümüz Türkçesiyle anlamı şöyledir;

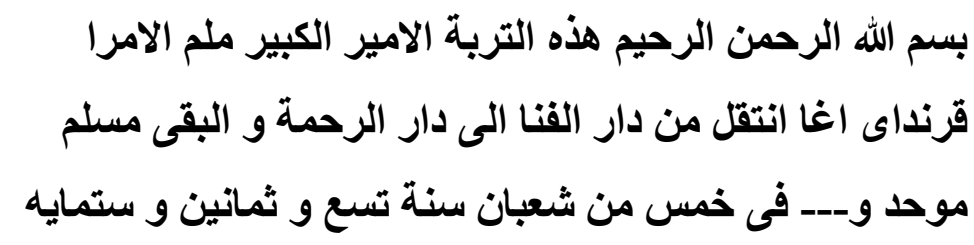

Bismillahirrahmanirrahim. Bu türbe büyük emir, emirler meliki Karanday Ağa'ya aittir. O fenâ âleminden rahmet ve bekâ âlemine 689 senesi Şaban ayının beşinde intikâl etti.

Miladî takvime çevrildiğinde bu tarih 13 Ağustos 1290’a tekabül etmektedir. Karanday Ağa ile ilgili kaynaklarda bilgiye ulaşılamamıştır ancak eserin kitabesinden anlaşıldığına göre kendisi bölgenin idaresinden sorumlu bir emir olmalıdır.

\section{SONUÇ}

Orta Asya'dan başlayan Türk kültürü ve sanatı, günümüzde Asya ve Anadolu sınırlarını da aşarak tüm dünyaya yayılmış durumdadır. İçinde bulunduğumuz bu çağda dahi ilk dönemlere ait kültür ve sanat geçmişimizin izlerini görmek mümkündür. Yapılan inceleme neticesinde Karanday Ağa kümbetinin kendi coğrafyasındaki diğer kümbetlerle aynı plan tipi ve süsleme özelliklerini taşıdığını söylemek mümkündür. Bu plan tipini basitçe açıklamak gerekirse, kare planlı kaide üzerine oturtulan silindirik gövdenin külah tipi konik örtüyle kapatılmasından elde edilen mimari yapı olarak tanımlayabiliriz. Kaide kısmı, içinde cenazelik (kripta) adı verilen bir odacığı barındırmaktadır. Bu odacığın üst tarafında ise silindir gövde ile kapatılmış ziyaret alanı yer almaktadır. Ziyaret alanın üstü ise birbirine çatılmış ağaç kütükleri misali konik bir örtü ile kapatılmıştır. Süsleme elemanları ise yıldız geçmelerden oluşan geometrik formlar, silmeler ve İslamiyet’in kabulü ile daha da gelişen bitkisel süsleme elemanlarıdır. Karanday Ağa kümbeti, Hüseyin Timur kümbeti ve diğer Anadolu Selçuklu dönemi kümbetlerine sanatsal açıdan 
önem katan bir başka unsur da bu yapıların kuşak ve kitabe gibi yazı içeren bölümleridir. Araştırmamız içinde bahsettiğimiz Selçuklu sülüsünün güzel örneklerini barındıran bu eserler Türk yazı sanatının 13. yüzyılda ne kadar gelişmiş olduğunu da göstermektedir. Daha geniş ölçekte bakıldığına Anadolu Selçuklu dönemi kümbetlerinin ana bölümlerini teker teker ele alırsak Orta Asya çadır kültürüne ait mimari elemanları görmemiz mümkündür. Kümbetlerdeki cenazelik (kripta), Orta Asya'da gördüğümüz kurganlardan sadece malzeme bakımından ayrılmaktadır. Erken dönemlerde malzemeye ulaşma ve elde edilen malzemeyi ihtiyaca göre şekillendirebilme noktasındaki kısıtlamalar tarihi süreç içerisinde giderilebilmiş ve ahşap malzemeden taş malzemeye geçiş gerçekleşmiştir. Benzer şekilde kümbetlerdeki ziyaret alanı adı verilen ve ölüyü ziyaret etmek için kullanılan bölüm, Orta Asya'da "yurt" adı verilen çadır formlarının biraz daha gelişmiş halidir diyebiliriz. Zira silindir gövdeli çadırların da üst kısmı konik şekilde sonlanan keçe ve çeşitli yaygılar ile kapatılmaktaydı. Kümbetlerde ise aynı form uygulanırken malzeme değişmiştir. Türklerin tarihi süreç boyunca Orta Asya'dan batıya doğru göçleri sırasında karşılaştıkları medeniyetlerden öğrenerek geliştirdiği bir takım teknikler mimari yapılarda açıkça görülebilmektedir. İran coğrafyasında gelişen tuğla tekniği, Anadolu'da büyük bir medeniyet kuran Anadolu Selçukluları tarafindan taş malzemeyle birleşmiş ve birbirinden eşsiz mimari eserlerin meydana getirilmesine vesile olmuştur.

Yapılan araştırmadan elde edilen bulgular ayrıca şunu da göstermektedir ki Türk toplumu, en ilkel dönemlerinden başlayarak ölü gömme, yaşamdan sonraki hayat inancı, ölüyü ziyaret etme, gerek mezara (kurgan) konulan kişisel eşyalar gerekse mezara dikilen balballar vasıtasıyla ölüyü onurlandırma gibi inançlara sahiptir. Bu tip inançların gelişmesi sanıldığı gibi göçebe bir toplumdan çok yerleşik veya uzun süreli olarak tanımlayabileceğimiz bir medeniyetin ürünü olmalıdır.

\section{KAYNAKÇA}

Arık, O., (1967), 13. Yüzyıla Ait Üç Kümbet, Anadolu Dergisi (11), 57-100.

Arseven, C. E. (1984). Türk Sanatı, Cem Yayınevi.

Çam, N. (2016). İslamda Sanat Sanatta İslam, Ankara: Akçağ Yayınları.

Çetintaş, Ö. (2018), Hüseyin Timur Kümbeti’nin Yazı ve Süsleme Özelliklerinin İncelenmesi Uluslararası İnsan ve Toplum Bilimleri Sempozyumu, Komrat Devlet Üniversitesi, 2018, Komrat, 128-133.

Çetintaş, Ö. (2019), Ankara Alaeddin Camii Kitabelerinin Hat Sanatı Yönünden İncelenmesi Güzel Sanatlar Enstitüsü Dergisi, (43), 193-199.

Çoruhlu, Y. (2017). Erken Devir Türk Sanatı İç Asya'da Türk Sanatının Doğuşunun ve Gelişimi, İstanbul: Kabalcı Yayıncılık.

Eldem, S. H. (1976). Türk Mimari Eserleri, İstanbul: Yapı Kredi Bankası Yayınları.

Erken, S. (1977). Türkiye'de Vakıf Abideler ve Eski Eserler II, Ankara: Vakıflar Genel Müdürlüğü Yayınları.

Karpuz, H. (2004). Anadolu Selçuklu Mimarisi, Konya: Selçuk Üniversitesi Yaşatma ve Geliştirme Vakfı Yayınları.

Mülayim, S. (1982). Anadolu Türk Mimarisinde Geometrik Süslemeler, Ankara: Kültür ve Turizm Bakanlığı Yayınları.

Ögel, S. (1987). Anadolu Selçukluları’nın Taş Tezyinatı, Ankara: Türk Tarih Kurumu Yayınları.

Öney, G. (1992). Anadolu Selçuklu Mimari Süslemesi ve El Sanatları, Ankara: Türkiye İş Bankası Kültür Yayınları.

Önkal, H. (2015). Anadolu Selçuklu Türbeleri, Ankara: Atatürk Kültür Merkezi Yayınları.

Sevim, A. (1988). Anadolu'nun Fethi Selçuklular Dönemi (Başlangıçtan 1086'ya Kadar), Ankara: Türk Tarih Kurumu Yayınlar1.

Söylemez, N. (2016). Anadolu'daki Türk İzleri, İstanbul: Uğur Tuna Yayınları.

Sözen M. \& Tanyeli U. (2014), Sanat Kavram ve Terimleri Sözlüğü, İstanbul: Remzi Kitabevi.

Şahin, M. K. (2014). Anadolu'da Selçuklu Dönemi Camileri I, Ankara: Merdiven Yayın.

Tunçer, O. C. (1976). 13. Yüzyıla Ait Üç Kümbet, Sanat Tarihi Yıllığg (6), 89-124.

Tunçer, O. C. (1978). Anadolu Türk Sanatı ve Yerli Kaynaklarla İlişkiler Üzerine Denemeler, Vakıflar Dergisi, (11), $239-270$. 